\begin{tabular}{|l|l|l||}
\hline \multicolumn{2}{|c|}{ PublisherInfo } \\
\hline \hline PublisherName & $:$ & BioMed Central \\
\hline \hline PublisherLocation & $:$ & London \\
\hline \hline PublisherImprintName & $:$ & BioMed Central \\
\hline \hline
\end{tabular}

\title{
Down-regulation of type I collagen by breast tumour cells
}

\begin{tabular}{|l|l|l||}
\hline \multicolumn{2}{|c||}{ ArticleInfo } \\
\hline \hline ArticleID & $:$ & 3668 \\
\hline \hline ArticleDOI & $:$ & $10.1186 /$ bcr-1999-66646 \\
\hline \hline ArticleCitationID & $:$ & 66646 \\
\hline \hline ArticleSequenceNumber & $:$ & 34 \\
\hline \hline ArticleCategory & $:$ & Paper Report \\
\hline \hline ArticleFirstPage & $:$ & 1 \\
\hline \hline ArticleLastPage & $:$ & 3 \\
\hline \hline & $:$ & RegistrationDate : 1999-12-23 \\
ArticleHistory & $:$ & OnlineDate $\quad$ 1999-12-23 \\
\hline \hline ArticleCopyright & $:$ & Current Science Ltd1999 \\
\hline \hline ArticleGrants & $:$ & \\
\hline \hline ArticleContext & $:$ & 1305822 \\
\hline \hline
\end{tabular}




\section{Keywords}

Breast cancer, collagen, extracellular matrix

\section{Introduction}

For invasion and subsequent metastasis, tumour cells must first degrade the surrounding extracellular matrix (ECM). Degradation of ECM depends on interactions between tumour and host cells. The principal component of ECM is type I collagen, which is synthesised mainly, but not exclusively, by fibroblasts. Production of collagenase by a variety of cell types can cause ECM degradation, and tumour cells themselves can modulate the function of fibroblasts, inducing them to produce this enzyme.

\section{Aims}

To investigate the relationship between synthesis of type I collagen and breast cancer stage.

\section{Comments}

It is now accepted that fibroblasts can no longer be regarded simply as supporting scaffold to maintain tissue architecture. This and other studies have revealed an important role for fibroblasts in tumour invasion. Although cell-cell contact appears to be a pre-requisite for this process, it will be interesting to understand the precise mechanism (s) by which this takes place.

\section{Methods}

Thirty primary infiltrating ductal carcinomas and their adjacent normal tissues were available. A portion of tissue was used for total RNA extraction and the remainder was formalin fixed and paraffin embedded. Extracted RNA was probed for alpha1(I) and alpha2(I) collagen by Northern blot analysis. Paraffin sections of the same samples were analysed by in situhybridisation using a digoxigenin-labelled 
riboprobe desiged to detect alpha1(I) collagen. Breast fibroblasts were generated from primary tissues and used in a coculture system with a range of breast tumour cell lines. Lung fibroblasts (WI-38) were also used. Tumour cell conditioned medium was collected from breast cell lines and used to determine the effects of soluble factors on collagen expression and synthesis by fibroblasts.

\section{Results}

Northern analysis of RNA extracts from 30 primary breast tumours showed stage I tumours had elevated levels of collagen mRNA compared with adjacent normal breast. Conversely, in stage II and III tumours, levels of collagen mRNA were reduced.In situhybridisation confirmed those changes and localised production of type I collagen to fibroblasts in the stroma surrounding the tumour cells. The tumour cells themselves were negative for collagen. To determine if tumour cells were directly responsible for alterated collagen expression, co-culture experiments were carried out. Established breast cancer cells lines were co-cultured with fibroblasts of breast or lung origin. In both cases, collagen synthesis was down-regulated by approximately $50 \%$, indicating that cell type rather than cell source was important. To determine if this was due to a soluble factor produced by tumour cells, breast fibroblasts were incubated with tumour cell conditioned medium. Whilst this reduced levels of collagen protein, the expression of collagen mRNA remained constant.

\section{Discussion}

This study has shown that tumour cells can modulate the production of collagen by stromal fibroblasts. While this was increased in stage I tumours, in more advanced cancers collagen production was downregulated. This is probably a mechanism to facilitate tumour cell invasion and metastic spread. This process appears to require direct cell contact.

\section{References}

1. Fenhalls G, Dent DM, Parker MI: Breast tumour cell-induced down-regulation of type I collagen mRNA in fibroblasts. Br J Cancer. 1999, 81: 1142-1149. 